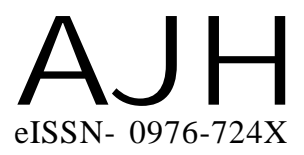

Article history :

Received : 23.04.2014

Revised : 02.10.2014

Accepted : 18.10 .2014
Author for correspondence

\section{S.K. BAIRAGI}

Department of Horticulture, Amar Singh P.G. College, Lakhaoti, BULANDSHAHR (U.P.) INDIA

Email : drskbairagi@gmail.com
THE ASIAN JOURNAL OF HORTICULTURE

Volume 9 | Issue 2 | Dec., 2014 |338-341

Visit us -www.researchjournal.co.in

\title{
Effect of different doses of phosphorus and row spacing on the yield and quality of fenugreek (Trigonella foenum-graecum L.) seed
}

\section{S.K. BAIRAGI}

ABSTRACT : Fenugreek, despite being widely cultivated in the northern states of India, its productivity (about $1,000 \mathrm{~kg} / \mathrm{ha}$ ) is quite low compared to the world average of about $1350 \mathrm{~kg} / \mathrm{ha}$. Among the various constraints in cultivation of this crop, non-availability of adequate quantity of good quality seed is considered to be a major factor. The present study, therefore, was conducted at Amar Singh PG College, Lakhaoti, Bulandshahr, Uttar Pradesh, during 2012-13 with an objective to standardize the optimum dose of phosphorus and ideal row spacing for obtaining maximum yield of good quality seed of fenugreek. Four different phosphorus (as single super phosphate) doses $\left(\mathrm{P}_{0}=0, \mathrm{P}_{3}=30, \mathrm{P}_{6}=60\right.$ and

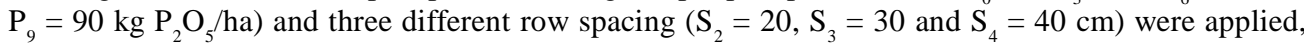
thereby making 12 treatment combinations. These 12 treatments were tested following RBDx3 and taking 'Pusa Early Bunching' as the experimental material. The results obtained from the experiment revealed that there was significant effect of different levels of phosphorus and row spacing on all the yield and contributing characters under study except, number of seeds per pod. The tallest plants (49.8 $\mathrm{cm}$ ), highest number of branches per plant (6.7) and number of pods per plant (50.5), maximum thousand seed weight $(18 \mathrm{~g})$ and seed yield $(1575 \mathrm{~kg} / \mathrm{ha})$ were observed with the application of $60 \mathrm{~kg}$ $\mathrm{P}_{2} \mathrm{O}_{5} /$ ha. Application of $60 \mathrm{~kg} \mathrm{P}_{2} \mathrm{O}_{5} /$ ha coupled with a row spacing of $30 \mathrm{~cm}$ was found to be most suitable for obtaining highest yield of good quality fenugreek seed in North Indian conditions.

KEY WORDS : Phosphorus doses, Row spacing, Fenugreek, Seed

HOW TO CITE THIS ARTICLE : Bairagi, S.K. (2014). Effect of different doses of phosphorus and row spacing on the yield and quality of fenugreek (Trigonella foenum-graecum L.) seed. Asian J. Hort., 9(2) : 338-341. 